\author{
A.K. Kaldarova ${ }^{1,2^{*}}$, T.A. Kulgildinova ${ }^{1}$, M. Vasquez ${ }^{2}$ \\ ${ }^{1}$ Ablai Khan Kazakh University of International Relations \\ and World Languages, Kazakhstan, Almaty \\ ${ }^{2}$ International Information Technology University, Kazakhstan, Almaty \\ *e-mail:a.kaldarova@edu.iitu.kz
}

\title{
IMPROVING STUDENTS' SPEAKING SKILLS IN AN ACADEMIC ENGLISH COURSE
}

This article summarizes the results of teaching Academic English course to the first year Intermediate level students. The article encompasses the activities for improving the speaking skills of learners. As required in the Academic English curriculum, optimizing the speaking skills of students is of those in macro skills that should be focused and enhanced with the aid of myriads of teaching tools. There were four Intermediate groups with a total of 32 students. Speaking tests were included in the first attestation midterm exam and final examination. Practice has shown that students also need to get rid of the fear of speaking in English, thereby helps to minimize or completely eliminate the fear associated with speaking English, which means constant and confident practice in the learning environment and beyond using various technical tools when studying or teaching English. The subject of the research is the improvement of speech skills among first year students, where students, learning a new vocabulary, train their speech skills during the semester. The study guidelines, various platforms for learning and teaching were used for the research. The study was conducted at one of the higher educational institutions of the city of Almaty, the International University of Information Technology. The results showed that thirty-two students had better results in the final exam than the midterm exam.

Key words: teaching foreign languages, speaking skill, assessment.

\author{
А.К. Калдарова ${ }^{1,2 *}$, Т.А. Кульгильдинова ${ }^{1}$, М. Васкез ${ }^{2}$ \\ ${ }^{1}$ Абылай хан атындағы Қазақ халықаралық қатынастар және \\ әлем тілдер университеті, Қазақстан, Алматы қ. \\ ${ }^{2}$ Халықаралық Ақпараттық Технологиялар Университеті, Қазақстан, Алматы қ. \\ *e-mail: a.kaldarova@edu.iitu.kz \\ Академиялық ағымшын тілі курсында студенттердің \\ сөйлеу дағдымарын жетікдіру
}

Бұл мақалада бірінші курс студенттеріне академиялық ағылшын тілі курсын оқытудың қорытындылары берілген. Мақалада ағылшын тілін оқыту үлерісінде сөйлеу дағдыларын жетілдіру үшін қолданылған жаттығулардың түрлері берілген. Академиялық ағылшын тілінің оқу жоспарының талаптарына сәйкес студенттерге әр апта сайын сөйлеу дағдыларын қалыптастыру мақсатында түрлі тақырыптар мен жағдаяттық тапсырмалар ұсынылды. Студенттердің сөйлеу Аағдыларын оңтайландыру үшін сөйлеу дағдыларын жүйелі түрде жетілдіруге әкелетін технологияларды қолдана отырып оқыту ұсынылды. Зерттеуге барлығы "Intermediate" деңгейдегі 32 студенттен құралған төрт топ қатысты. Сөйлеу қабілетін тексеруге арналған тестілер аралық, бақылау емтиханға және қорытынды емтиханға енгізілді. Тәжірибе көрсеткендей, студенттерге ағылшын тілінде сөйлеу қорқынышынан арылу керек, бұл ағылшын тілінде сөйлесуге байланысты қорқынышты азайтуға немесе толықтай жоюға көмектеседі және оқу кезіндегі тұрақты және сенімді тәжірибені көрсетеді, сонымен қатар әр түрлі техникалық құралдарды қолдану арқылы ағылшын тілін үйрену немесе оқыту болып табылады. Зерттеу пәні - бірінші курс студенттерінің сөйлеу дағдыларын жетілдіру, мұнда студенттер жаңа лексиканы үйреніп, семестр барысында сөйлеу дағдыларын жаттықтырады. Зерттеу үшін оқу құралдары, оқыту мен оқытуға арналған түрлі платформалар қолданылды. Зерттеулер Алматы қаласының жоғары оқу орындарының бірінде, Халықаралық ақпараттық технологиялар университетінде жүргізілді. Зерттеу нәтижесінде отыз екі студент аралық бақылауға қарағанда қорытынды емтиханында жақсы нәтиже алғанын көрсетті.

Түйін сөздер: шетел тілін оқыту, сөйлеу қабілеті, бағалау. 


\author{
А.К. Калдарова ${ }^{1,2 *}$, Т.А. Кульгильдинова ${ }^{1}$, М. Васкез ${ }^{2}$ \\ ${ }^{1}$ Казахский университет международных отношений и мировых языков \\ имени Аблай хана, Казахстан, г. Алматы \\ ${ }^{2}$ МежАународный Университет Информационных Технологий, Казахстан, г. Алматы \\ *e-mail: a.kaldarova@edu.iitu.kz \\ Совершенствование речевых навыков студентов \\ в курсе академического английского языка
}

\begin{abstract}
В данной статье рассмотрены итоги обучения по курсу академического английского языка студентам первого курса уровня "Intermediate". В статье по методике преподавания английского языка предлагаются примеры упражнений, которые использовались Аля обучения английскому языку по всем видам речевой деятельности. Согласно требованиям учебной программы по академическому английскому языку, отраженной в силмабусе, каждую неделю студентам предлагались различные темы на говорение. Подчеркивается, что оптимизировать речевые навыки необходимо с помощью технологий, которые системно веАут к совершенствованию речевых навыков студентов. Всего было четыре группы, в которых обучались 32 человека. Устные тесты были вк^ючены в первый промежуточный аттестационный экзамен и финальный экзамен. Практика показала, что студентам также необходимо избавиться от страха говорить по-английски, что помогает свести к минимуму или полностью устранить страх, связанный с разговором по-английски, что означает постоянную и уверенную практику в учебной среде и помимо использования различных технических средств при обучении или обучение английскому языку. Предметом исследования является совершенствование речевых навыков у студентов первого курса, гАе студенты, изучая новый словарный запас, тренируют речевые навыки в течение семестра. Аля исследования были использованы учебные пособия, различные платформы Аля обучения и преподавания. Исследование проводилось в одном из высших учебных заведений города Алматы - Международном университете информационных технологий. Согласно результатам исследования, тридцать два студента показали кучшие результаты на финальном экзамене, чем на промежуточном.
\end{abstract}

Кмючевые слова: обучение иностранному языку, разговорные навыки, оценка.

\section{Introduction}

This article outlines the experience of teaching Academic English course to the first year Intermediate level students. The course is designed to help students develop their English language competence for their current and future academic studies. The course focuses on building up general/academic vocabulary, raising their grammar accuracy and developing academic Listening, Reading, Writing and Speaking skills. Intensive classwork is accompanied by self-study activities in the form of SIS (selfchecked language and grammar exercises plus project presentation), and TSIS (academic speaking and writing). By the end of the course the students will be able to guess the meaning of unfamiliar words, correctly use the studied grammar constructions; to demonstrate general and detailed understanding of oral speech in academic situations; to demonstrate the skills of skimming and scanning texts with high frequency academic and general language; to interpret and summarize academic texts and to speak on academic topics using the studied language [1] (Academic program of the IYa course, 2020).

We would like to point out that we will highlight how students worked in order to improve their speaking skills in this work. The students were given different communicative activities. The research methodology and the research results are presented in the article as well.

\section{Literature review}

The questions of teaching and learning foreign languages have become the most important issues these days. We can find the answers to different questions regarding foreign language teaching in S.S. Kunanbayeva's book; her work outlines an integrated theory of modern foreign language learning (FLL) and it is devoted to the theory and practice of foreign language education [2] (Kunanbayeva, 2010). In addition, many researchers have been working on problems of formation and development of the communicative competence of learners as well. There are also different works on the development of students' speaking skill and assessing it properly.

Carnegie Mellon University states that the goal of formative assessment is to monitor student learning to provide ongoing feedback that can be used by instructors to improve their teaching and by students to improve their learning. Formative assessments oc- 
cur throughout the period of the learning process in order to identify and determine which factors of the design work well for the students, while summative assessment is to evaluate student learning at the end of an instructional unit by comparing it against some standard or benchmark. Summative assessments are often high stakes, which means that they have a high point value [3] (Carnegie Mellon University, n.d.).

Brown H.D. suggests that there are at least are six criteria to assess speaking skill and they are pronunciation, fluency, grammar, vocabulary, discourse features and task accomplishments [4] (Brown, 2007).

Focusing on speaking skill, Brown H.D. and Abeywickrama P. propose five types of speaking and they are: imitative, intensive, responsive, interactive, and extensive [5] (Brown, Abeywickrama, 2010).

According to A.S. Bazarbayeva, the student will be interested when he works with enthusiasm, when he experiments and when he acquires new knowledge by himself for using it in the future [6] (Bazarbayeva,2019). So, it is better to practice different speaking activities where students will solve the problems, offer solutions to them, create something new and present them to the groupmates. This will motivate them to learn a new language. Moreover, $\mathrm{K}$. Ruzieva underlines that the most important in helping students to activate their knowledge is to create the "safe" situations at the lessons, where learners are inspired and motivated to try to speak a foreign language [7] (Ruzieva, 2020).

\section{Research design}

Thirty-two students with Intermediate level of English studied online for about fifteen weeks. They studied online using Microsoft Teams, Zoom, Moodle and other platforms. The aims of the course were to develop the students' skills of speaking on a wide range of academic topics and to foster the students' interest in learning, develop their logical and critical thinking. creativity, leadership, decision-making, problem solving and team work abilities, etc.

Various speaking topics were given to students every week according to the topics, and they were all indicated in the syllabus. With this, the learners could easily prepare, and probably learnt the speech by heart prior to the lesson itself. The teacher did not just let the students express themselves, but also asked questions based on what they had spoken. They were not just being assessed to these themes but also in the following tasks such as describing something, telling a story, comparing things, giving some personal information, oral presentation (proj- ect), interactive tasks, etc. The following speaking activities were given to students: interviews, jigsaw tasks, guessing games, questioning activities, discussion activities, problem-solving activities, etc. Various teaching methodologies with the help of technologies are used to improve the speaking levels of the learners.

These are samples which are given in the course book "Headway Academic Skills Listening, Speaking and Study Skills. Level3"; this course book is used in teaching Academic English course to the students [8] (Richard Harrison, 2011):

1. Topic: Assessing study skills. A specific online application tool was used, padlet, in order to monitor the progress of the students. Posting texts, images, documents, links, videos, etc. related to topics given can be incorporated in the application and at the same they can do collaborative learning.

0 . Decide what your strengths and weaknesses are: Good at working with others; Note-taking in lectures; Meeting deadlines.

a. Think about your study habits. Answer these questions and write notes. 1 When do you like to study? At weekends in the mornings. 2 Where do you like to study? 3 Do you take regular breaks? 4 Do you take notes while studying? 5 Do you make plans for your study time and free time? 6 Do you like to study alone or in a group?

b. Work in pairs or small groups. Discuss your strengths, weaknesses and study habits. Use the expressions in the Language Bank (They are given in the course book for students).

0 . Topic: Organizing a presentation. An online application called mindmeister allows the learners to visualize, share and present their thoughts via cloud. This was also recommended to students as part of their learning progress for them to mind map their thoughts and ideas prior to their speaking project presentation.

Work in groups and think about presentations you have seen in the past. Discuss these questions: What makes a good presenter? What makes a bad presenter? Use the diagrams to record your ideas (Figure 1):
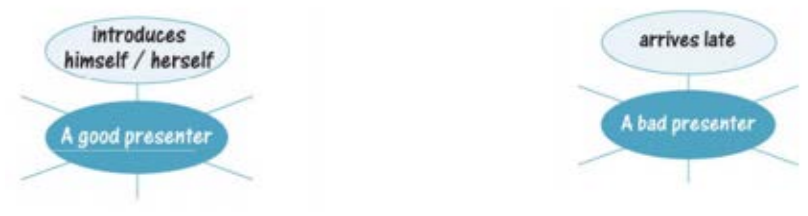

Figure 1 - What makes a good /bad presenter? (from Headway Academic Skills Listening, Speaking and Study Skills. Level 3. Student's book) 
b. Look at the quotation below. It is common advice for people learning how to make a good presentation. What do you think it means? Discuss in small groups. "Tell them what you are going to tell them. Tell them. Then tell them what you have told them."

0. Prepare a short introduction to a presentation on your project work. Use some of the information you collected. Use the headings to plan your introduction (Figure 2). Use expressions from the Language Bank to help you (They are given in the course book for students):

Title (Explain the title of the talk)

Definition (Explain any terms)

Reasons (Why did you choose this topic?)

Aims / Objectives

(What do you aim to do?)

Plan (What is the structure of the talk?)

Figure 2 - Making a presentation

(from Headway Academic Skills Listening, Speaking and Study Skills. Level 3. Student's book)

d. Give your introduction to the class. Briefly discuss the presentations. Did students cover the main points in their introductions? Were the introductions successful? Were you interested? Did you want to find out more about the topic?

0 . Topic: Giving and supporting opinions. Another feature to increase the learners' ability using technology specifically the Microsoft Teams is by group work. Splitting the class into pair, or triad whatever the lesson needs, plausible, and there the learners could share and interact freely with the supervision of the teacher.

0 . Imagine that all the textbooks you need for your course of study are available on an e-reader. Would you choose to buy one, or would you prefer to use books? Discuss your ideas with a partner.

a. You are going to discuss the benefits of new technologies. Work in small groups and follow the stages. 1-Each person should choose one of the following topics: Facebook; Laptop computers; Plastic surgery; Mobile phones; 3D films. 2-Research information on the topic. 3-Prepare to give your opinions on the topic. Find ways to support your point of view and consider views opposing your own.

\section{Research results}

Students were administered summative tests (first attestation and second attestation) both on first and second semesters to determine the progress of the students. They composed of Vocabulary and grammar tests, Speaking, Listening, Writing and project presentation depending on the subject. In addition, for final examinations, the test included writing and speaking tests. According to the course calendar, students had the midterm speaking test in week \#8 and final exam speaking test in week \#16. Figure 3 shows the result of each group.

\begin{tabular}{|c|c|c|}
\hline Groups & $\begin{array}{c}\text { Midterm exam } \\
\text { Speaking test } \\
\text { results-100\% }\end{array}$ & $\begin{array}{c}\text { Final exam } \\
\text { Speaking test } \\
\text { results-100\% }\end{array}$ \\
\hline IS 5,6,7 (6ss) & 75 & 88.5 \\
\hline MCM+CS (10 ss) & 76.36 & 85.73 \\
\hline CSSE 10-11 (7ss) & 68.57 & 74.13 \\
\hline RET/Physics (9ss) & 78.88 & 96.67 \\
\hline
\end{tabular}

Figure 3 - The results of speaking tests-midterm and final exams

Figure 4 illustrates the changes in the results of speaking skills of 32 students with Intermediate level.

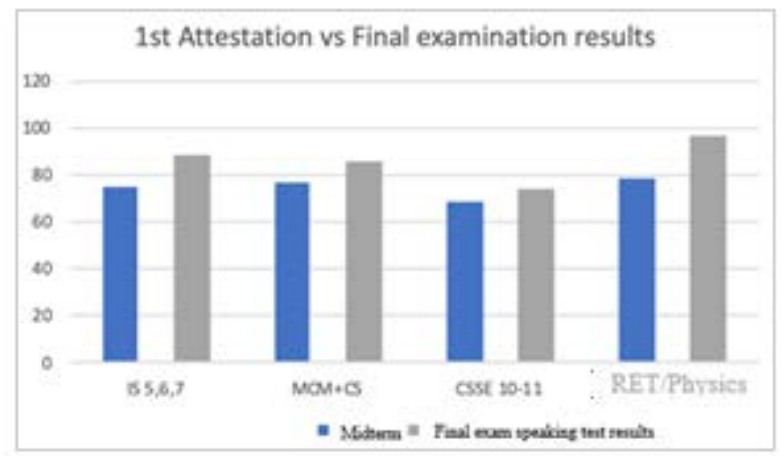

Figure 4-Comparison of speaking test results

Students from "IS 5,6,7" group improved their speaking skill, it increased from $75 \%$ in midterm to $88.5 \%$ in final exam. Furthermore, students of "RET and Physics" group showed the highest result in final exam. It rose dramatically from $78.88 \%$ in midterm to $96.67 \%$ in final exam. The results of speaking of "MCM\&CS" group increased sharply from $76.36 \%$ to $85.73 \%$. The biggest change was 
in "CSSE 10\&11" group's speaking results, it expanded slowly from $68.57 \%$ in midterm to $74.13 \%$ in final exam.

\section{Research discussion}

There were four Intermediate groups with a total of 32 students. All of them passed the speaking part of the examination. The result ranges from $68 \%$ $-90 \%$. Speaking tests were included in first attestation midterm exam and final examination. The data contributes a clearer understanding of comparison of first attestation versus the final examination. Students were more prepared in the final speaking tests compared to the first attestation speaking examination. The activities which were used in teaching/ learning English language in these fifteen weeks were useful and helpful for students. Fulcher G. said that the success of a learning program is commonly determined by the result of assessment [9] (Fulcher, 2003).

In addition, we analyzed the answers of students accordingly. Interpreting Fig. 3, it is evident that group CSSE 10-11 in comparison with others had the lowest result from the midterm speaking test but not considered as a failing mark. However, all speaking topics were based on the main modules of the Syllabus. There were two part of them: Module 1- My Kazakhstan and Module 2- Cultural and historical background. Sample midterm speaking test topics such as: "Describe a famous building in your country, city or town? What was the last famous building you visited? Which type of architecture do you find ugly? Do you think we should preserve old buildings, or knock them down? Which city has the best architecture, Almaty or Nur-Sultan? Do you prefer modern architecture or classic architecture? Should we take care to preserve some of the classic buildings from the past? How has architecture changed over the last 200 years? What would it be like in the future?" etc. were all taken into consideration that each question should be relevant to modules tackled.

As for the final exam speaking topics, it covered the third module of the program which was entitled "Education". These were the final speaking topics samples: "Sports ought to be a major part of the education system; The pros and cons of globalization; Your learning style. (Do you learn best by listening, reading, interaction, doing things, or by some other method? School uniforms should be required" etc.

Scrutinizing the results of midterm and final speaking tests, it is conspicuous that there were huge differences between them. The main reasons are the followings:

1. Student's fear of failure: For some students, adjustment period was their great struggle. It was their transition from school to university and learning styles were somewhat impacted them. So, it was difficult to start working regularly. At the beginning of the semester, cheating was inevitable. They tried to sneak and read their notes or texts, but teachers caught them which resulted them to earn in low marks. Most of the learners were more focused on their study after getting the low results for the midterm speaking test, and learned the consequences of cheating.

2. No physical learning environment set up between the teacher and students: Speaking face to face is a natural way to communicate to one another and to get across your ideas more effectively. Unfortunately, students had to pass their first midterm exam online. This resulted students to struggled to focusing on the screen while having speaking exam.

3. Improved Student Performance: Most students were enlightened the importance of regular preparation for classes and by the end of the semester they improved their results. Hopefully, at the second attestation period they worked better and the results improved.

4. Technology issue: Since students studied online, issues such as poor and weak Internet connection hindered their performances in midterm exam. They tried to fix them during a certain period of time before final speaking tests.

5. Speaking test criteria: Criteria on speaking tests were introduced several times until the final examination. Students knew what was expected from them, what they had to focus on when they pass speaking test. It included the following criteria: Structure/ cohesion; Task completion; Vocabulary range; Grammar accuracy; Fluency.

\section{Conclusion}

We know that it is important to give students some useful phrases which contain some active vocabularies. In this case, students can have interesting, exciting and insightful conversations with each other. It is also essential to take into consideration that assessment on speaking can be a very judgmental issue, in which people tend to relate on native/nonnative speakers on the basis of pronunciation [10] (Luoma, Sari 2004). According to some researchers, students should get rid of English speaking fear as well. Minimizing or completely eliminating the fear the to speak English is to practice constantly 
and confidently in and out of the learning environment by using different tech tools in learning/teaching English language. The next point is that selftalk is advised for students who want to practice at home. Student can record himself/herself and listen to it for any wrong pronunciation; he/she can also ask feedback from a teacher or groupmates. To sum up, practice makes perfect, so students should speak English in plenty.

Based on our research, we can conclude this work by giving some recommendations on solving the issues mentioned in the previous part of the article:

1. Syllabus and its aims, policy should be thoroughly introduced to students in week \#1. Anticheating measures and online proctoring systems should be put in place by any online education institution and they should be practiced before examinations. Learners should focus on formulating their thoughts, generating ideas, and expressing their knowledge effectively in English rather than learning the texts from the Internet.

2. Students are studying online now, so they can practice their speaking anytime with different Mobile Apps, such as Zoom, Google Meet, Skype, and Microsoft Teams. Every application includes unlimited conference calls, screen sharing, video conferencing, recording, etc. The speaking activities mentioned in this paper can be used with these applicationss as well.

3. Time management and organizational skills are necessary to achieve the aims of the course programs. Students should allot enough time on completing each speaking task and balance the study with their other priorities in their lives. It requires strong self-motivation and self-discipline skills as well.

4. If students study online and they have to improve their speaking skill by having video calls, then they need the high bandwidth or the strong internet connection that does not fail to catch up with their virtual classmates. Learners should properly equip themselves for the course's successful completion.

5 . The evaluation parameters of the speaking tests should be introduced in week \#1, and if possible upload it on respective website (in our case, DL- student's portal) or hand them a copy. Knowing them beforehand would help students master the targeted criteria and gain confidence in order to succeed in improving speaking skill.

\section{References}

1 Академическая программа курса IYa 1203i Academic English. Кафедра языков. Международный университет информационных технологий. - Алматы, 2020.

2 Кунанбаева, С. С. Теория и практика современного иноязычного образования. - Алматы: Дом печати «Эдельвейс», 2010.

3 Carnegie Mellon University, Eberly Center. What is the difference between formative and summative assessment? https:// www.cmu.edu/teaching/assessment/basics/formative-summative.html

4 Bazarbayeva, A. Новые подходы диалогового обучения в высшей школе с позиции обновленной программы // Вестник КазНУ. Серия педагогическая, 61(4), 146-153. doi:10.26577/JES.2019.v61.i4.013

5 Рузиева К. Общение - это основной инструмент развития разговорной речи: Монография Pokonferencyjna. Наука, исследования, разработки \# 27. Варшава, 2020. http://xn--e1aajfpcds8ay4h.com.ua/files/01_iv_2020_s.pdf

6 Richard Harrison. Series Editors: Liz and John Soars. Headway Academic Skills Listening, Speaking and Study Skills. Oxford University Press, 2011.

7 Brown, H. D. \& Abeywickrama, P. Language assessment: principles and classroom practice (2nd ed.). New York: Pearson Education Inc., 2010.

8 Fulcher, G. Testing second language speaking. London: Longman/Pearson Education, 2003.

9 Brown, H. D. Teaching by principles: An Interactive approach to language pedagogy (3rd ed.). New York: Pearson Education Inc., 2007.

10 Luoma, Sari. Assessing speaking. - Cambridge: Cambridge University Press, 2004.

\section{References}

Akademicheskaya programma kursa IYa 1203i Academic English. Kafedra yazykov. Mezhdunarodnyy universitet informatsionnykh tekhnologiy (2020) [Academic English Department of Languages. Academic program of the course IYa 1203i. International Information Technology University]. Almaty, 2020. (In Russian)

Bazarbayeva, A. (2019) New Approaches in Teaching Dialogue in High School From Position of Updated Program. Al-Farabi Kazakh National University, Journal of Educational Sciences 61(4), 146-153. doi:10.26577/JES.2019.v61.i4.013

Brown H. D. \& Abeywickrama, P. (2010) Language assessment: principles and classroom practice 2nd ed. New York: Pearson Education Inc. 
Brown H. D. (2007) Teaching by principles: An Interactive approach to language pedagogy (3rd ed.). New York: Pearson Education Inc.

Carnegie Mellon University, Eberly Center. What is the difference between formative and summative assessment? https://www. cmu.edu/teaching/assessment/basics/formative-summative.html

Fulcher G. (2003) Testing second language speaking] London: Longman/Pearson Education

K. Ruzieva (2020) Communication is a basic tool for developing speaking skill. Monografia Pokonferencyjna. Science, Research, Development \#27. Warszawa. http://xn--e1aajfpcds8ay4h.com.ua/files/01_iv_2020_s.pdf

Kunanbayeva, S. S. (2010) Teoriya i praktika sovremennogo inoyazychnogo obrazovaniya [Theory and practice of modern foreign language education] Almaty: Edelveiss Printing House, p. 94-261. (In Russian)

Luoma, Sari. (2004) Assessing speaking Cambridge Cambri-dge University Press.

Richard Harrison. (2011) Series Editors: Liz and John Soars. Headway Academic Skills Listening, Speaking and Study Skills Oxford University Press 